\title{
PENGARUH PEMBELAJARAN LABORATORIUM VIRTUAL BERBASIS INKUIRI TERHADAP PEMAHAMAN KONSEP OPTIK pada SISWA KELAS XII SMA NEGERI 1 MARAWOLA
}

\author{
Armaeni, Unggul Wahyono dan Kamaluddin \\ e-mail: irmaarmaeni@yahoo.co.id \\ Program Studi Pendidikan Fisika FKIP Universitas Tadulako \\ Jl. Soekarno Hatta Km. 9 Kampus Bumi Tadulako Tondo Palu - Sulawesi Tengah
}

\begin{abstract}
Abstrak - Penelitian ini bertujuan untuk mengetahui pengaruh pembelajaran laboratorium virtual berbasis inkuiri terhadap pemahaman konsep optik pada siswa kelas XII SMA Negeri 1 Marawola. Jenis penelitian yang digunakan adalah kuasi eksperimen dengan desain penelitian "The Non Equivalen Pretest-Posttest Design" . Populasi penelitian ini adalah seluruh siswa kelas XII SMA Negeri 1 Marawola, dengan sampel penelitian kelas XII B sebagai kelas eksperimen berjumlah siswa 21 orang dan kelas XII C sebagai kelas kontrol dengan jumlah siswa 22 orang. Instrumen yang digunakan berupa tes pemahaman konsep dalam bentuk pilihan ganda. Berdasarkan hasil pengolahan data, diperoleh rerata skor pretest pemahaman konsep siswa kelas eksperimen adalah 9,69 dan untuk posttest adalah 20,43. Untuk kelas kontrol diperoleh rerata skor pretest 8,97, untuk posttest adalah 16,45 . Analisis data tes dilakukan dengan teknik statistik uji-t satu pihak diperoleh nilai hasil $t_{\text {hitung }}=3,12$ dan $t_{\text {tabel }}=2,02$ dengan demikian $\mathrm{Ho}$ ditolak dan $\mathrm{H}_{1}$ diterima. Penelitian ini menujukan bahwa terdapat pengaruh pembelajaran laboratorium virtual berbasis inkuiri terhadap pemahaman konsep optik pada siswa kelas Xii SMA Negeri 1 Marawola.
\end{abstract}

Kata Kunci: Pembelajaran Laboratorium Virtual, Model pembelajaran konvensional, pemahaman konsep optik

\section{PENDAHULUAN}

Laboratorium adalah tempat riset ilmiah, eksperimen, pengukuran ataupun pelatihan ilmiah dilakukan. Laboratorium biasanya dibuat untuk memungkinkan dilakukannya kegiatankegiatan tersebut secara terkendali. Laboratorium diartikan sebagai suatu tempat untuk mengadakan percobaan, penyelidikan, dan sebagainya yang berhubungan dengan ilmu fisika, kimia, dan biologi atau bidang ilmu lain. [1]

Secara garis besar fungs laboratorium dalam proses pendidikan adalah : Sebagai tempat untuk berlatih mengembangkan keterampilan intelektual melalui kegiatan pengamatan, pencatatan dan pengkaji gejala-gejala alam, mengembangkan keterampilan motorik siswa, siswa akan bertambah keterampilannya dalam mempergunakan alat-alat media yang tersedia untuk mencari dan menemukan kebenaran, memberikan dan memupuk keberanian untuk mencari hakekat kebenaran ilmiah dari sesuatu objek dalam lingkungn alam dan sosial,memupuk rasa ingin tahu siswa sebagai modal sikap ilmiah seseorang calon ilmuan, membina rasa percaya diri sebagai akibat keterampilan dan pengetahuan atau penemuan yang diperolehnya. ${ }^{[1]}$

Akan tetapi, pada faktanya masih terdapat banyak sekolah yang belum memiliki laboratorium, sehingga siswa kurang bersikap aktif. Ahkirnya siswa sulit memahami materi yang diajarkan karena sebagian besar hanya mendengarkan penjelasan guru tanpa terlibat langsung dalam kegiatan pembelajaran. Sehingga penguasaan konsep siswa yang kurang optimal pada saat kegiatan di laboratorium, siswa juga terlihat kurang aktif dan cenderung diam jika ditanya oleh guru. Selain hal tersebut, seringkali siswa asyik berbicara dengan teman atau cenderung diam jika diberi persoalan oleh guru. Hal tersebut mengindikasikan proses pembelajaran belum berlangsung secara interaktif.

Berdasarkan uraian tersebut, diperlukan tindak lanjut yang serius dari guru agar tujuan pembelajaran dapat tercapai secara optimal. Perwujudan dari tindak lanjut mengarah pada perbaikan mutu pembelajaran.

Oleh sebab itu peneliti akan menerapkan pembelajaran laboratorium virtual. Sehingga tidak adanya kecemburuan sosial antara sekolah yang mempunyai fasilitas laboratorium 
yang memadai dengan sekolah yang sama sekali tidak mempunyai fasilitas laboratorium.

\section{RUMUSAN MASALAH}

Bagaimana pengaruh pembelajaran laboratorium virtual berbasi inkuiri terhadap pemahaman konsep optik pada siswa kelas XII SMA Negeri 1 Marawola.

\section{METODE PENELITIAN}

Penelitian ini menggunakan metode eksperimen kuasi. ${ }^{[2]}$ Desain penelitian yang digunakan adalah "The Non Equivalen PretestPosttest Design" desain penelitian tersebut dilaksanakan pada dua kelompok yaitu kelompok kontrol dan kelompok eksperimen. Penelitian ini menggunakan kelas-kelas yang sudah ada sebagai kelompoknya. Bentuk desainnya disajikan pada Tabel $1 .{ }^{[3]}$

Tabel 1 Desain Penelitian

\begin{tabular}{|l|c|c|c|}
\hline \multicolumn{1}{|c|}{ Kelompok } & $\begin{array}{c}\text { Tes } \\
\text { Awal }\end{array}$ & perlakuan & Tes Akhir \\
\hline Eksperimen & $\mathrm{O}_{1}$ & $\mathrm{X}_{1}$ & $\mathrm{O}_{2}$ \\
Kontrol & $\mathrm{O}_{1}$ & - & $\mathrm{O}_{2}$ \\
\hline
\end{tabular}

Keterangan :

$\mathrm{O}_{1}$ :Tes Awal

$\mathrm{O}_{2}:$ Tes Akhir

$\mathrm{X}$ : Perlakuan dengan Pembelajaran

laboratorium virtual berbasis inkuiri

Penelitian ini dilaksanakan di SMA Negeri 1 Marawola yang merupakan salah satu Sekolah Menengah Atas Negeri di Marawola yang bertempat di Jln Trans Palu Bangga Kec. Marawola. Adapun populasi penelitian ini adalah seluruh siswa kelas XII SMA Negeri 1 Marwola tahun pelajaran 2014/2015, dengan jumlah populasi 65 orang siswa yang tersebar dalam tiga kelas, sampel dalam penelitian ini adalah kelas XII B dan kelas XII C.

\section{HASIL DAN PEMBAHASAN}

\section{1) Hasil Analisis Instrumen}

Berdasarkan hasil validitas ahli, disetujui sebanyak 36 soal pilihan ganda dari 40 soal. Selanjutnya soal diuji cobakan, berdasarkan hasil uji coba diperoleh hasil tes yang reliabel.

\section{2) Dasar-Dasar Analisis}

Sebelum dilakukan uji perbedaan ratarata, data diuji dengan menggunakan uji normalitas dan uji homogenitas. Setelah diuji dengan uji normalitas diketahui bahwa baik data kelas eksperimen maupun kelas kontrol untuk preetest dan posttest keduanya berasal dari populasi yang terdistribusi normal. Selanjutnya dilakukan uji homogenitas, diperoleh data preetest dan prosttest pada kelas eksperimen dan kelas kontrol memiliki variansi yang homogen.

\section{3) Uji Perbedaan Rata-Rata}

Berdasarkan hasil perhitungan diperoleh nilai $t_{\text {hitung }} 3,12 t_{\text {tabel }} 2,02$ atau $t_{\text {hitung }}>t_{\text {tabel }}$. Dengan demikian $\mathrm{H}_{0}$ ditolak dan $\mathrm{H}_{1}$ diterima. Hal ini menujukan bahwa ada perbedaan pemahaman konsep optik antara kelas eksperimen dengan kelas kontrol. Sehingga dapat disimpulkan bahwa terdapat pengaruh pembelajaran laboratorium virtual terhadap peningkatan pemahaman konsep optik pada siswa kelas X II SMA Negeri 1 Marawola.

\section{PEMBAHASAN}

Pada penelitian ini terdapat 2 sampel yang digunakan yaitu kelas eksperimen dan kelas kontrol. Pada kelas eksperimen menggunakan pembelajaran laboratorium virtual berbasis inkuiri, sedangkan kelas kontrol menggunakan pembelajaran konvensional. Berdasarkan hasil analisis data tes awal diketahui bahwa data terdistribusi normal. Hasil skor rata-rata kelas ekperimen dan kelas kontrol berada dalam varians yang sama (homogen).

Setelah kedua kelas menggunakan pembelajaran yang berbeda, maka hasil analisis data tes akhir menunjukkan perolehan skor rata-rata berbeda pada kelas eksperimen dan kelas kontrol. Hasil analisis data skor rata-rata tes akhir laboratorium virtual berbasis inkuiri lebih besar daripada skor rata-rata pembelajaran konvensional. Pada pembelajaran laboratorium virtual berbasis inkuiri siswa dituntut untuk menemukan sendiri konsepkonsep optik melalui percobaan media simulasi. Contohnya pada dispersi,pada saat siswa melakukan simulasi mengenai dispersi siswa dapat melihat proses peruraian warna cahaya dari prisma yaitu cahaya polikromatik yang terurai menjadi cahaya monokromatik. Dalam hal ini siswa lebih aktif dengan menggunakan simulasi serta siswa dapat lebih fokus memperhatikan peruraian cahaya yang terjadi dalam simulasi, karena siswa diberi kesempatan oleh guru untuk melakukan percobaan serta menemukan konsep atau 
pemahamannya sendiri mengenai peruraian cahaya tersebut.

Perolehan skor pada kelas yang menggunakan pembelajaran laboratorium virtual berbasis inkuiri lebih tinggi dari pada kelas yang menggunakan konvensional. Hal ini dikarenakan siswa diberikan kesempatan untuk mencari sendiri pemecahan masalah dengan kerjasama kelompok dan dituntut untuk menghubungkan materi optik yang dipelajari dengan kehidupan sehari-hari sehingga siswa lebih mudah memahami materi yang diberikan dan siswa cendrung lebih aktif dengan menggunakan simulasi. Dengan demikian, siswa pada kelas eksperimen tingkat pemahaman lebih tinggi dibanding kelas kontrol karena siswa dituntut untuk secara aktif membangun sendiri pengetahuannya baik secara pribadi maupun kelompok. Karena, dengan siswa yang aktif dan menemukan sendiri apa yang mereka pelajari dan menggabungkan dengan pemahaman mereka, maka siswa cenderung mengingat dan memahami tentang konsep optik yang diberikan. Dengan cara pembelajaran seperti ini maka siswa menjadi pusat pembelajaran sedangkan guru hanya sebagai fasilitator. Sementara perolehan skor pada kelas yang menggunakan pembelajaran konvensional lebih rendah. Hal ini disebabkan oleh guru yang lebih efektif dibandingkan siswa yang hanya menerima sehingga suasana belajar cenderung monoton yang mengakibatkan pelajaran fisika itu sulit dipahami dan dimengerti.

Penerapan media virtual laboratorium berbasis inkuiri berpengaruh terhadap hasil belajar siswa. ${ }^{[4]}$ Dibandingkan dengan hasil penelitian yang dilakukan peneliti, menggunakan pembelajaran laboratorium virtual berbasis inkuiri yang di uji cobakan pada kelas ekperimen sedangkan kelas kontrol mengunakan model pembelajaran Konvensional diperoleh rata-rata tes akhir kelas eksperimen yaitu 20,48 dan untuk kelas kontrol diperoleh rata-rata tes akhir yaitu 16,45. Hal ini membuktikan bahwa pembelajaran laboratorium virtual berbasis inkuiri lebih baik dari pembelajaran Konvensional.

Kedua model pembelajaran ini memiliki kelebihan dan kelemahan masing-masing pada pembelajaran laboratorium virtual kelebihannya yaitu mengurangi keterbatasan waktu, mengurangi hambatan geografis, ekonomis, tidak membutuhkan bangunan lab, alat-alat dan bahan-bahan seperti pada laboratorium ril, meningkatkan keamanan dan keselamatan, karena tidak berinteraksi dengan alat dan bahan kimia yang nyata. Kelemahan dalam Laboratorium Virtual yaitu kurangnya pengalaman secara riil di laboratorium nyata, sehingga terjadi kebingungan peserta didik dalam merangkai alat dan mengoperasikannya. ${ }^{[5]}$ Sedangkan kelemahan model pembelajaran konvensional yaitu siswa cenderung monoton dan hanya menerima materi yang dipelajari. Dari hasil penelitian ini dapat dilihat bahwa pemahaman konsep siswa yang menggunakan pembelajaran laboratorium virtual lebih baik dari pada siswa yang mengikuti pembelajaran menggunakan model pembelajaran konvensional.

\section{KESIMPULAN}

Berdasarkan hasil penelitian dan analisa data, serta $u j i$ statistik diperoleh nilai $t_{\text {hitung }}>t_{\text {tabel }}$ atau 3,12>2,02 artinya $\mathrm{H}_{0}$ ditolak dan $\mathrm{H}_{1}$ diterima. Maka dapat disimpulkan bahwa terdapat pengaruh pembelajaran laboratorium virtual berbasis inkuiri terhadap pemahaman konsep optik pada siswa kelas XII SMA Negeri 1 Marawola.

\section{DAFTAR PUSTAKA}

[1] Mustaphaawan. 2011. Pengertian dan fungsi laboratorium. Tersedia pada. http://wanmustafa.wordpress.com. (Diunduh pada 15 Juli 2014).

[2] Sugiyono. 2010. Metode Penelitia Pendidikan: Kuantitatif, Kualitatif dan $R \& D$. Bandung: Alfa Beta

[3] Sugiyono. (2008). Metode Penelitian Pendidikan. Bandung: Alfabeta.

[4] Nurrokhmah, IE dan Sunarto, W. 2013. Pengaruh penerapan virtual terhadap hasil belajar kimia labs. Tersedia pada. http://journal.unnes.ac.id/sju/index.php/chemined. (Diunduh pada 15 Juli 2014).

[5] Mazguru. 2012. Memanfaatkan laboratorium virtual. Tersedia pada. http://mazguru.wordpress.com. (Diunduh pada 15 Juli 2014). 